\title{
Mixed Reality (MR) dalam Pembelajaran Folklor dalam Perspektif Guru Dan Siswa Sekolah Dasar
}

\author{
Yunus Abidin, Tita Mulyati, Yeni Yuniarti, Tri Falah Nur Huda \\ Universitas Pendidikan Indonesia \\ Corresponding Email: yunusabidin@upi.edu, tita@upi.edu, yeni_yuniarti@upi.edu, trifalah@upi.edu
}

\begin{abstract}
The development of the 21st century has had a major impact on developments in various aspects of life including economic, social, and educational aspects. In this regard, education in the 21st century is faced with a number of major challenges, one of which is to develop students who are technologically literate but also culturally literate. Thus, there is a need for a change to the pattern of learning in Indonesian education today that further develops high knowledge, understanding, and skills in line with 21st century technological advances but still ignores core cultural knowledge. In line with this, the first step in realizing this research is to design a mixed reality (MR)-based folklore learning media to develop students' learning abilities and cultural literacy. In line with this, the research aims to determine the perspectives of teachers and elementary school students in West Java on the use of mixed reality in folklore learning. This research was conducted using a descriptive method. The instruments used to collect data are observation guidelines, interview guidelines, and questionnaires. The data was processed using descriptive statistics. Based on the results of the study, it can be stated that the mixed reality media used in folklore learning in the view of teachers and students in elementary schools in West Java is able to motivate students to learn and the media developed is considered very good in quality, function, and benefits.
\end{abstract}

Keywords:

folklore; media; mixedreality

\begin{abstract}
Abstrak
Perkembangan abad 21 ini telah berdampak besar terhadap perkembangan dalam berbagai aspek kehidupan termasuk aspek ekonomi, sosial, dan pendidikan. Sehubungan dengan hal tersebut, pendidikan di abad 21 dihadapkan dengan sejumlah tantangan besar yang salah satunya adalah membangun para siswa yang literat teknologi tetapi juga literat budaya. Dengan demikian, perlu adanya sebuah perubahan terhadap pola pembelajaran dalam pendidikan Indonesia saat ini yang lebih mengembangkan pengetahuan, pemahaman, dan keterampilan yang tinggi sejalan dengan kemajuan teknologi abad ke-21 namun masih abai terhadap pengetahuan inti budaya. Sejalan hal tersebut, langkah awal dalam merealisasikan penelitian ini adalah merancang bangun media pembelajaran folklore berbasis mixed reality (MR) untuk mengembangkan kemampuan belajar dan literasi budaya siswa. Sejalan dengan hal tersebut penelitian bertujuan untuk mengetahui perspektif guru dan siswa sekolah dasar di Jawa Barat terhadap penggunaan mixed reality dalam pembelajaran folklor. Penelitian ini dilaksanakan dengan menggunakan metode deskriptif. Instrumen yang digunakan untuk mengumpulkan data adalah pedoman observasi, pedoman wawancara, dan kuesioner. Data diolah dengan menggunakan statistika deskriptif. Berdasarkan hasil penelitian dapat dikemukakan bahwa media mixed reality yang digunakan dalam pembelajaran folklor dalam pandangan guru dan siswa di sekolah dasar di Jawa Barat mampu memotivasi siswa belajar dan media yang dikembangkan dinilai sangat baik secara kualitas, fungsi, dan manfaatnya.
\end{abstract}

Kata Kunci:

folklor; media; mixedreality

\section{A. PENDAHULUAN}

Abad ke-21 merupakan abad yang ditandai dengan terjadinya perubahan dalam berbagai aspek kehidupan terutama dalam perkembangan teknologi dan informasi. Perkembangan 
teknologi dan informasi di abad ke-21 sangat pesat sehingga biasa disebut dengan era digitalisasi informasi. Perkembangan teknologi dan informasi di abad ke-21 ini pun dapat membawa dampak ke dalam berbagai aspek kehidupan manusia yang nyatanya manusia lebih cenderung ketergantungan terhadap teknologi. Berhubungan dengan hal di atas, dunia pendidikan di abad ke- 21 ini berada dalam titik perkembangan yang sangat signifikan dengan berbagai macam permasalahan yang muncul di beberapa tingkatan atau jenjang pendidikan. Permasalahan-permasalahan yang muncul dalam dunia Pendidikan di abad ke-21 ini adalah kurangnya pengembangan bahan ajar yang mengolaborasikan antara isi materi pembelajaran dengan kemajuan teknologi informasi di abad ke-21.

Sejalan dengan perkembangan tersebut, pembelajaran folklor di sekolah dasar dianggap sebagai salah satu pembelajaran yang membosankan, tidak menarik, dan bahkan dianggap sesuatu yang kuno. Hal ini dikarenakan peran guru dalam mengolah pembelajaran tidak disejalankan dengan perkembangan teknologi informasi di abad ke-21 dan masih cenderung masih dilakukan secara konvensional dan menggunakan media pembelajaran yang tidak menarik dan tertinggal zaman. Hal ini berdampak pada menurunnya minat dan motivasi belajar siswa serta berimbas pada penurunan hasil belajar serta semakin mengkhawatirkannya literasi budaya siswa. Kondisi ini menuntut adanya sebuah inovasi baru dalam pembelajaran yang dapat membuat peserta didik memiliki ketertarikan yang besar, sehingga pembelajaran tidak berjalan dengan penuh paksaan melainkan pembelajaran dapat menjadi sesuatu yang sangat menyenangkan. Salah solusi tersebut adalah mengembangkan media pembelajaran folklor yang sejalan dengan perkembangan teknologi yakni salah satunya media pembelajaran berbasis Mixed Reality (selanjutnya disebut MR).

Dikembangkannya media pembelajaran folklor berbasis MR tidak terlepas dari beberapa penelitian yang menunjukkan bahwa MR memiliki dampak positif besar terhadap pembelajaran. Tolentino. et al (2009) menjelaskan bahwa penerapan MR dalam proses pembelajaran dapat meningkatkan kemampuan siswa dalam hal keterampilan berpikir dan penalaran, pembelajaran yang kolaboratif, serta dapat mengembangkan pengetahuan konseptual. Lebih lanjut, Essmiller. et al (2020) menjelaskan bahwa peluang untuk membuat pembelajaran menjadi bermakna melalui penggunaan MR sangat terbuka serta media ini mampu pula membuat siswa sanggup mengeksplorasi fasilitas dan kesempatan belajar ini melalui redistribusi beban kognitif. Dengan demikian pemanfaatan MR dalam pembelajaran dapat meningkatkan berbagai aspek kemampuan siswa. Selain itu juga, bahwa penerapan mixed MR dapat dijadikan sebagai penunjang pendekatan pembelajaran STEM (Barrett. et all [2018] ; Yanier, Hudson \& Koedinger [2020]).

Strzys. et al (2017) menjelaskan bahwa MR adalah penggabungan dua virtualitas menjadi satu dengan penggunaan teknologi imersif berbentuk kacamata yang memungkinkan seseorang dapat berinteraksi di dalamnya. Lindgren \& Johnson-Glenberg (2013) menjelaskan bahwa lingkungan MR menggabungkan dunia digital dengan dunia fisik (nyata), 
seperti contoh siswa dapat menggunakan tubuh mereka untuk menstimulasikan orbit di sekitar planet virtual.

Berkaitan dengan hal di atas, bahwa teknologi MR mengintegrasikan komponen dunia nyata dengan media digital interaktif untuk menawarkan potensi baru dalam hal menggabungkan praktik terbaik dalam pembelajaran sains tradisional dengan kemampuan simulasi audio/visual yang canggih (Tolentino. et al, 2009). Atas dasar ini, penggunaan media pembelajaran berbasis MR diyakini mampu meningkatkan mutu pembelajaran folklor yang di sisi lain dipandang sebagai bahan ajar yang telah usang dan membosankan. Padahal, folklor merupakan bagian dari budaya yang terdapat di masing-masing daerah yang menjadi ciri khas budaya dari daerah tersebut. Dalam folklor mengandung norma-norma kehidupan bermasyarakat berdasarkan adat istiadat sekitar. Khairani \& Baiduri (2017) mengungkapkan folklor berawal dari tradisi lisan masyarakat, sarat dengan pesan nilai dan moral yang ingin disampaikan dalam satu generasi kepada generasi penerus. Folklor dapat dijadikan sebagai sarana untuk membimbing anak berperilaku baik karena mengandung banyak nasehat yang dapat dijadikan pelajaran hidup. Lebih lanjut, Lee, Lee \& Lau (2006) menjelaskan bahwa pembelajaran berbasis cerita rakyat adalah sejenis paradigma pembelajaran yang terletak di mana siswa belajar dengan memecahkan masalah yang tertanam dalam situasi yang hampir nyata.

Dipima, \& Aklmar (2019) menjelaskan bahwa sastra rakyat atau cerita rakyat dianggap sebagai bentuk sastra paling awal di semua budaya manusia. Ini mencakup semua tradisi yang indah, sebagian besar bersifat lisan, yang dipraktikkan oleh budaya dan subkultur. Selain itu, MorganFleming (2015) menjelaskan mengenai lima konsep dan fungsi folklor yaitu; (1) redefinisi kompetensi linguistik dan komunitas linguistik; (2) pandangan teks yang muncul dari struktur sosial yang dituturkan; (3) penekanan pada norma dan aturan yang ditentukan secara lokal untuk perilaku linguistik; (4) peran tradisi dan inovasi dalam cerita rakyat; dan (5) kritik feminisme dan revisi cerita rakyat.

Selain memiliki fungsi di atas, folklor juga dipandang sebagai sebuah alat yang tepat untuk membangkitkan literasi budaya siswa yang sudah memudar. Hui \& Cheung (2015) mengungkapkan bahwa literasi budaya mengacu pada pandangan dunia individu, cara berinteraksi dengan orang, karakter, etika pribadi, nilai dan gaya hidup. Literasi budaya juga dapat diartikan sebagai konteks kesadaran berbudaya (Moncada, 2016; Dean, 2017; Shulsky, Baker, Chvala, \& Willis, 2017; Schaefer \& Lynch, 2017).

Johnson (2014) menjelaskan bahwa literasi budaya berawal dari konsep kosmopolitanisme yaitu sebagai perwujudan identitas seseorang (etnis, nasional, budaya) dan modal budaya yang terakumulasi melalui pengalaman dengan proses pendidikan. Lebih lanjut, literasi budaya telah digunakan untuk pengembangan berbagai perspektif dalam proses pengajaran (Mason \& Giovanelli, 2017; Reygan \& Steyn, 2017). Lebih lanjut, Ochoa, McDonald, \& Monk (2016) mengungkapkan bahwa penerapan Literasi Budaya adalah keterampilan yang dapat dikembangkan sebagai hasil dari pemahaman dan penerapan keterampilan dan konsep yang melekat. Selain itu, bahwa literasi budaya dapat diartikan sebagai proses 
interaksi sosial dalam hal berkomunikasi dan berkolaborasi dengan masyarakat sekitar. Dapat dipahami bahwa dengan memiliki keterampilan literasi budaya, seseorang dapat meningkatkan interaksi sosialnya dan dapat juga meningkatkan pengetahuan terhadap norma yang berlaku di sekitarnya.

Atas dasar berbagai hal di atas, untuk memulihkan fungsi penting folklor tersebut dikembangkanlah media pembelajaran folklor berbasis teknologi MR. Namun demikian kelayakan dan keberterimaan media pembelajaran folklor berbasis MR masih perlu diuji secara khusus. Oleh sebab itu, penelitian ini memiliki tujuan utama untuk memaparkan perspektif guru dan siswa sekolah dasar di Jawa Barat terhadap media pembelajaran folklor berbasis teknologi MR ditinjau dari aspek kualitas, fungsi, dan manfaatnya.

\section{B. HASIL DAN PEMBAHASAN}

Penelitian ini berupaya mengungkap perspektif guru dan siswa sekolah dasar di Jawa Barat terhadap penggunaan media pembelajaran berbasis MR dalam pembelajaran folklor. Tujuannya yaitu untuk mendapatkan respons berupa tanggapan dan saran dari guru sebagai pengajar dan siswa yang belajar menggunakan media pembelajaran ini. Responden penelitian ini meliputi 28 orang guru dan 249 orang siswa SD di Jawa Barat. Hasil penelitian ini dijabarkan sebagai berikut.

\section{Perspektif Guru}

Untuk mengetahui perspektif guru terhadap media MR folklor dilakukan dua jenis cara pengumpulan data yakni melalui observasi dan wawancara. Observasi merupakan hal pertama yang dilakukan peneliti untuk mengamati tingkah laku/sikap guru saat mengoperasikan media MR Folklor. Guru terlihat antusias ketika menyimak penjelasan terkait penggunaan media pada awal penelitian. Ketika menggunakan media guru tampak serius membaca petunjuk penggunaan yang berada pada buku. Guru juga tampak senang ketika mendengar bahwa aplikasi dapat digunakan secara offline. Tidak ditemukan masalah yang berarti saat mengoperasikan media ini. Media MR Folklor mendapatkan respons positif dari sudut pandang guru. Guru terlihat antusias dan takjub saat mengoperasikan media MR Folklor. Data secara lengkap tanggapan guru adalah sebagai berikut.

Tabel 1. Tanggapan Guru terhadap Media MR Folklor

\begin{tabular}{|c|l|c|c|c|c|c|}
\hline No. & \multicolumn{1}{|c|}{ Aspek } & $\begin{array}{c}\text { Jumlah } \\
\text { butir }\end{array}$ & $\begin{array}{c}\text { Jumlah } \\
\text { Guru }\end{array}$ & $\begin{array}{c}\text { Skor } \\
\text { Ideal }\end{array}$ & $\begin{array}{c}\text { Perolehan } \\
\text { Skor }\end{array}$ & $\begin{array}{c}\text { Persentase } \\
(\%)\end{array}$ \\
\hline 1 & Kelayakan Isi/Materi & 7 & 28 & 980 & 900 & 91,84 \\
\hline 2 & Komponen Penyajian & 4 & 28 & 560 & 550 & 98,21 \\
\hline 3 & Komponen Kebahasaan & 3 & 28 & 420 & 400 & 95,24 \\
\hline 4 & Kontekstual & 3 & 28 & 420 & 410 & 97,62 \\
\hline 5 & $\begin{array}{l}\text { Kualitas Teknis dan } \\
\text { Desain Aplikasi MR }\end{array}$ & 8 & 28 & 1120 & 1120 & 100,00 \\
\hline 6 & Buku Marker & 9 & 28 & 1260 & 1232 & 97,78 \\
\hline 7 & Kualitas Media & 2 & 28 & 280 & 280 & 100,00 \\
\hline
\end{tabular}


Kelayakan isi/materi menurut sudut pandang guru SD sudah sangat sesuai dan memenuhi indikator-indikator penilaian yang meliputi: (1) kesesuaian isi dengan $\mathrm{KD}$, (2) kesesuaian isi dengan silabus, (3) kesesuaian isi dengan indikator, (4) kedalaman materi, (4) kebenaran konsep materi ditinjau dari aspek keilmuan, (5) ketepatan visualisasi materi, (6) kesesuaian dengan perkembangan ilmu. Diperoleh skor persentase sebesar $91,84 \%$ yang diinterpretasikan bahwa produk yang dikembangkan termasuk "Sangat Baik" dari segi isi/materi.

Komponen penyajian media MR Folklor ditinjau dari indikator yang meliputi: (1) kelogisan penyajian, (2) keruntutan penyajian, (3) koherensi, dan (4) kesesuaian dan ketepatan objek ${ }_{3} \mathrm{D}$ yang muncul, memperoleh skor persentase sebesar $98,21 \%$ yang diinterpretasikan bahwa produk yang dikembangkan termasuk "Sangat Baik" baik dari segi komponen penyajian aplikasi maupun buku MR Folklor. Media pembelajaran MR Folklor ini memiliki sedikit komponen kebahasaan. Pada aplikasi dan buku lebih banyak diisi oleh ikon-ikon dan gambar. Berdasarkan sudut pandang ahli, komponen kebahasaan media MR Folklor yang dilihat berdasarkan indikator kebahasaan meliputi: (1) penggunaan dan penyajian bahasa sesuai dengan tingkat perkembangan siswa, (2) ketepatan tata bahasa dan ejaan yang digunakan, dan (3) ketepatan dalam penggunaan simbol yang mewakili kata dapat mudah dipahami, memperoleh skor persentase sebesar 95,24\% yang diinterpretasikan bahwa produk yang dikembangkan termasuk " Sangat Baik".

Media MR folklor ini juga dapat dinilai kontekstual melalui indikator yang meliputi: (1) ketertarikan materi yang disajikan dengan kehidupan dunia nyata siswa, (2) kemampuan mendorong siswa membuat hubungan antara pengetahuan yang dimiliki dengan penerapannya dalam kehidupan sehari-hari, dan (3) pemodelan (modelling). Berdasarkan tanggapan guru terkait komponen kontekstual media MR Folklor, skor persentase yang diperoleh sebesar 97,62\% yang diinterpretasikan bahwa produk yang dikembangkan termasuk "Sangat Baik" dari segi kontekstual.

Kualitas teknis dan desain aplikasi teknologi MR memperoleh persentase penilaian sebesar $100 \%$ yang menandakan bahwa kualitas media "Sangat Baik" dengan indikator yang meliputi: (1) penampilan unsur tata letak tombol-tombol navigasi pada aplikasi memudahkan pengguna, (2) kejelasan pelafalan audio pada aplikasi, (3) kemenarikan desain tampilan aplikasi sesuai dengan karakteristik siswa, (4) penggunaan komposisi warna harmonis dan enak dilihat, (5) objek $3 \mathrm{D}$ yang muncul, (6) aplikasi membantu dalam mengenalkan folklor, (7) menarik perhatian, dan (8) mudah diakses kapan saja dan di mana saja.

Penilaian media berupa buku marker memiliki indikator yang meliputi: (1) kesesuaian ukuran buku yang mudah dibawa, (2) kesesuaian ukuran buku dengan isi materi, (3) desain sampul/cover buku menarik, (4) kualitas kertas buku tidak mudah rusak, (5) kerapian tata letak teks dan gambar yang ada pada buku, (6) warna yang digunakan sesuai dengan karakteristik peserta didik, (7) gambar yang digunakan menarik, menggambarkan materi ajar, dan (9) marker mudah dibaca. Persentase yang diperoleh sebesar $97,78 \%$ dan dapat 
diinterpretasikan bahwa buku marker "Sangat Baik".

Kualitas media meliputi aplikasi dengan fitur MR dan buku marker yang sudah dicetak. Indikator penilaian kualitas media meliputi: (1) kegunaan media untuk mengenalkan Folklor, dan (2) kegunaan media dalam memfasilitasi siswa untuk aktif dalam pembelajaran. Kualitas media memperoleh persentase $100 \%$, yang berarti kualitas media "Sangat Baik".

Kesimpulannya, secara keseluruhan perolehan skor persentase rata-rata media MR Folklor dari sudut pandang guru sebesar 97,24\% yang diinterpretasikan bahwa media MR Folklor tergolong ke dalam kategori "Sangat Baik" dan sudah laik guna.

Untuk memperkuat temuan tersebut, peneliti melakukan wawancara dengan beberapa guru tersebut. Guru sebagai responden diberikan kebebasan untuk memberikan jawaban berupa tanggapan, pendapat, maupun ideidenya sesuai dengan pertanyaan yang diajukan. Berdasarkan wawancara ini diperoleh informasi bahwa hampir seluruh responden belum pernah mendengar atau mengetahui mengenai teknologi berbasis MR. Hal ini tergambar dari ekspresi guru yang antusias ketika mengoperasikan media MR folklor. Guru menyatakan bahwa penyajian materi mengenalkan Folklor berbantuan MR bagus dan sangat menarik. Visualisasi dengan bantuan objek 3D juga sudah sesuai. Guru juga menyatakan bahwa media MR Folklor cukup mudah digunakan, mengingat media disertai dengan petunjuk penggunaan yang disertai simbolsimbol sehingga tidak terdapat gangguan yang berarti selama penggunaan media. Guru merasa tertarik menggunakan media pembelajaran di kelas dan tidak terdapat kritik atau saran karena guru merasa media MR Folklor sudah layak digunakan.

\section{Perspektif Siswa}

Sama halnya ketika mengumpulkan data dengan responden guru, perspektif siswa pun dikumpulkan dengan menggunakan pedoman wawancara, lembar observasi, Bedanya untuk perspektif siswa digunakan kuesioner sejalan dengan banyaknya responden yang diteliti. Berdasarkan hasil observasi, diketahui bahwa seluruh responden yakni siswa sekolah dasar yang diamati terlihat antusias dan mendengarkan dengan baik saat peneliti memperkenalkan media. Peneliti mendokumentasikan kegiatan melalui foto dan video saat siswa mengujicobakan media. Meskipun responden tampak malu-malu, namun mereka tetap berebutan menggunakan media MR folklor. Responden diberikan kebebasan untuk menjelajah media yang dikembangkan pada satu judul folklor yang rata-rata berdurasi 6 menit. Siswa tampak sangat antusias dan termotivasi mempelajari cerita rakyat menggunakan media pembelajaran MR ini. Selanjutnya, data secara lengkap tanggapan siswa dengan menggunakan kuesioner terhadap media MR folklor disajikan adalah sebagai berikut

Tabel 2. Tanggapan Siswa terhadap Media MR Folklor

\begin{tabular}{|l|l|c|c|c|c|c|}
\hline No. & \multicolumn{1}{|c|}{ Aspek } & $\begin{array}{c}\text { Jumlah } \\
\text { butir }\end{array}$ & $\begin{array}{c}\text { Jumlah } \\
\text { Siswa }\end{array}$ & $\begin{array}{c}\text { Skor } \\
\text { Ideal }\end{array}$ & $\begin{array}{c}\text { Perolehan } \\
\text { Skor }\end{array}$ & $\begin{array}{c}\text { Persentase } \\
\text { (\%) }\end{array}$ \\
\hline o1.0o & Isi/Materi & $\mathbf{1}$ & 249 & 1245 & 1190 & 95,58 \\
\hline 02.0o & Ketertarikan Aplikasi MR & 9 & 249 & 11205 & 11200 & 99,96 \\
\hline 03.0o & Buku Marker & 3 & 249 & 3735 & 3569 & 95,56 \\
\hline
\end{tabular}




\begin{tabular}{|l|l|c|c|c|c|c|}
\hline No. & Aspek & $\begin{array}{c}\text { Jumlah } \\
\text { butir }\end{array}$ & $\begin{array}{c}\text { Jumlah } \\
\text { Siswa }\end{array}$ & $\begin{array}{c}\text { Skor } \\
\text { Ideal }\end{array}$ & $\begin{array}{c}\text { Perolehan } \\
\text { Skor }\end{array}$ & $\begin{array}{c}\text { Persentase } \\
\text { (\%) }\end{array}$ \\
\hline \multicolumn{2}{|l|}{ Rata-rata } & & 97,03 \\
\hline
\end{tabular}

Isi yang dinilai yaitu aspek media MR Folklor yang memudahkan siswa dalam memahami folklor karena disajikan multimodal mendapatkan skor sebesar 95,58\% yang mengindikasikan bahwa media MR folklor memiliki kualitas "Sangat Baik". Ketertarikan siswa terhadap aplikasi MR memperoleh skor 99,96\% yang dilihat dari aspek antara lain: (1) penyajian materi folklor menarik, (2) media membuat siswa senang belajar, (3) media membuat siswa tidak bosan belajar mengenal folklor, (4) media memotivasi siswa belajar, (5) tomboltombol navigasi pada aplikasi mudah digunakan, (6) kejelasan pelafalan audio pada aplikasi, (7) desain aplikasi menarik, (8) komposisi warna nyaman dilihat, (9) objek 3D muncul. Berdasarkan 9 aspek tersebut, ketertarikan siswa terhadap aplikasi MR mendapatkan kualitas "Sangat Baik". Selanjutnya Buku marker yang dilihat dari segi (1) sampul buku menarik, (2) kualitas kertas buku marker, dan (3) marker yang mudah dipindai mendapatkan skor 95,56 yang menandakan bahwa aplikasi MR Folklor memiliki kualitas "Sangat Baik. Persentase rata-rata yang diperoleh sebesar 97,03\%, yang diinterpretasikan bahwa media pembelajaran secara keseluruhan tergolong "Sangat Baik" menurut siswa dan layak digunakan meskipun terdapat gangguan yang tidak berarti.

Berdasarkan hasil wawancara yang dilakukan secara individual terhadap beberapa siswa, didapatkan informasi berupa tanggapan positif siswa terhadap media MR Folklor. Siswa menyebutkan bahwa media sangat membantu belajar mengenal folklor dan literasi budaya yang dikandungnya. Hal ini dibuktikan oleh siswa yang menjawab dengan benar ketika mereka menjawab kuis interaktif yang ada dalam aplikasi tersebut. Siswa juga menyatakan bahwa mereka senang dan semangat belajar menggunakan media MR folklor. Siswa menjawab bahwa media mudah digunakan dan tidak terdapat kesulitan saat menggunakan media karena siswa hanya diarahkan untuk memilih tombol "AR Kamera" dan membuka buku folklor dan disediakan kotak VR untuk menonton video animasi berbasis VR. Musik latar dan dialog pada media juga terbilang cukup nyaring dan membuat siswa antusias ketika membuka aplikasi. Siswa secara beragam menyebutkan kesan belajar menggunakan media MR Folklor menyenangkan dan cepat memahami isi folklor.

Berdasarkan hasil penelitian di atas, dapat dikemukakan bahwa media pembelajaran folklor dengan menggunakan teknologi MR telah berhasil menarik minat belajar siswa dan minat guru menggunakannya dalam pembelajaran. Keberhasilan ini sejalan dengan Liu. et al (2007) yang mengungkapkan bahwa MR merupakan media yang berbasiskan teknologi terbaru yang dapat dieksplorasi sebagai media edutainment, menjanjikan potensi untuk merevolusi pembelajaran dan pengajaran, membuat pengalaman peserta didik lebih "menarik". Selain itu, Barrett. et al (2018) menjelaskan bahwa sistem mixed reality (MR) memberikan solusi baru karena kemampuannya untuk memelihara kolaborasi dan interaksi. 
Ketertarikan siswa dan guru terhadap media yang dikembangkan juga sangat beralasan. Berdasarkan hasil penelitiannya Marty. et al (2015) menjelaskan bahwa cara memperoleh pengetahuan selama sesi pembelajaran mirip dengan mengikuti petualangan dalam permainan role playing dan mereka menerapkan metafora menjelajahi dunia virtual, setiap siswa memulai sebuah pencarian untuk mengumpulkan pengetahuan yang terkait dengan sebuah kegiatan belajar. Essmiller. et al (2020) memperkuat bahwa MR membuat peluang untuk pembelajaran yang menarik dan bermakna. Alasan-alasan tersebut sangat sejalan dengan alasan-alasan responden penelitian ini baik guru maupun siswa sekolah dasar.

\section{SIMPULAN}

Berdasarkan hasil penelitian dapat dikemukakan bahwa perspektif guru dan siswa sekolah dasar di Jawa Barat terhadap media pembelajaran folklor berbasis teknologi MR ditinjau dari aspek kualitas, fungsi, dan manfaatnya berkategori sangat baik. Lebih lanjut guru juga menyatakan bahwa media MR Folklor cukup mudah digunakan serta tertarik menggunakan media pembelajaran ini di kelas dan mereka juga menilai media MR Folklor sudah layak digunakan. Siswa secara beragam menyebutkan kesan belajar menggunakan media MR Folklor menyenangkan dan cepat memahami isi folklor dan mereka merasa semakin termotivasi jika belajar menggunakan media MR folklor.

\section{DAFTAR PUSTAKA}

Baiduri, R., \& Khairani, L. (2017, December). Revitalization of Value and Meaning Toba Batak Folklore in the Formation of
Character Education of Children. In 2nd International Conference on Social and Political Development (ICOSOP 2017) Atlantis Press.

Barrett, R., Gandhi, H. A., Naganathan, A., Daniels, D., Zhang, Y., Onwunaka, C., ... \& White, A. D. (2018). Social and tactile mixed reality increases student engagement in undergraduate lab activities. Journal of Chemical Education, 95(10), 1755-1762.

Dean, S. R. (2017). Development and Validation of a Multicultural Consciousness Instrument. Journal of Student Affairs Research and Practice, 54(2), 175-188.

Dipima, B., \& Aklmar, M.S. (2019). Blending folklore with technology as language teaching and learning tools: role and impact.

Essmiller, K., Asino, T. I., Ibukun, A., Alvarado-Albertorio, F., Chaivisit, S., Do, T., \& Kim, Y. (2020). Exploring mixed reality based on self-efficacy and motivation of users. Research in Learning Technology, 28.

Hui, S. K. F., \& Cheung, H. Y. (2015). Cultural literacy and student engagement: The case of technical and vocational education and training (TVET) in Hong Kong. Journal of Further and Higher Education, 39(4), 553-578.

Johnson, P. C. (2014). Cultural literacy, cosmopolitanism and tourism research. Annals of Tourism Research, 44, 255-269.

Lee, J. H. M., Lee, F. L., \& Lau, T. S. (2006). Folklore-based learning on the web- pedagogy, case study, and evaluation. Journal of Educational Computing Research, 34(1), 1-27.

Lindgren, R., \& Johnson-Glenberg, M. (2013). Emboldened by 
embodiment: Six precepts for research on embodied learning and mixed reality. Educational researcher, $42(8), 445452$.

Liu, W., Cheok, A. D., Mei-Ling, C. L., \& Theng, Y. L. (2007). Mixed reality classroom: learning from entertainment. In Proceedings of the and international conference on Digital interactive media in entertainment and arts (pp. 65-72).

Marty, Jean-Charles., et al. (2015). "Mixed Reality Games." International Journal of GameBased Learning, vol. 5 .

Mason, J., \& Giovanelli, M. (2017). 'What do you think?'Let me tell you: Discourse about texts and the literature classroom. Changing English, 24(3), 318-329.

Moncada L. S. (2016). Othering: Towards a critical cultural awareness in the language classroom. How, 23(1), 129-146.

Morgan-Fleming, B. (2015). Teaching as performance: Connections between folklore and education. Curriculum Inquiry, 29(3), 273-291.

Ochoa, G., McDonald, S., \& Monk, N. (2016). Embedding cultural literacy in higher education: a new approach. Intercultural Education, 27(6), 546-559.

Reygan, F., \& Steyn, M. (2017). Diversity in basic education in South Africa: Intersectionality and critical diversity literacy. Africa Education Review, 14(2), 68-81.

Schaefer, Z. A., \& Lynch, O. H. (2017). A novel approach to London: Infusing ethnography and the study abroad experience. Communication Teacher, 31(2), 112115.

Shulsky, D. D., Baker, S. F., Chvala, T., \& Willis, J. M. (2017). Cultivating Layered Literacies: Developing the
Global Child to Become Tomorrow's Global Citizen. International Journal of Development Education and Global Learning, 9(1), 49-63.

Strzys, M. P., Kapp, S., Thees, M., Kuhn, J., Lukowicz, P., Knierim, P., \& Schmidt, A. (2017). Augmenting the thermal flux experiment: A mixed reality approach with the HoloLens. The Physics Teacher, 55(6), 376-377.

Tolentino, L., Birchfield, D., MegowanRomanowicz, C., JohnsonGlenberg, M. C., Kelliher, A., \& Martinez, C. (2009). Teaching and learning in the mixed-reality science classroom. Journal of Science Education and Technology, 18(6), 501-517.

Yannier, N., Hudson, S. E., \& Koedinger, K. R. (2020). Active Learning is About More Than Hands-On: A Mixed-Reality AI System to Support STEM Education. International Journal of Artificial Intelligence in Education, 1-23. 